\title{
Preferences, Country Bias, and International Trade
}

\author{
Santanu Roy and Jean-Marie Viaene*
}

\begin{abstract}
The paper analyzes international trade in a Ricardian world where consumer preferences exhibit country bias. In particular, consumers differentiate between identical physical goods by country of manufacture. In contrast to the classical Ricardian model, the pattern of international specialization in production depends on the preference structure. Possible equilibrium configurations include ones where both countries specialize incompletely and trade in both commodities, as well as situations where the pattern of specialization and trade is the reverse of that in the classical Ricardian world. Both interindustry and intraindustry trade can occur simultaneously, though there are no market imperfections or scale economies.
\end{abstract}

\section{Introduction}

The existence of country bias in consumer preferences is a widely observed phenomenon. Nowadays, products are almost universally labelled by country of manufacture. Consumers are often willing to pay different amounts for physically similar goods manufactured in different countries, as they carry different nonphysical associations. Such associations arise from various factors like reputation about quality of products manufactured by certain countries, information and beliefs about the process of manufacture in different countries, and associations of noneconomic nature reflecting social or political bias.

There are many reasons why such biases could arise. Some of them have to do with environmental or other forms of social "consciousness" among consumers. Suppose that production of a commodity causes pollution or environmental damage in the country in which it is produced. For simplicity, assume there are no trans-frontier effects. The spread of knowledge among consumers in the country about the damage caused by pollution could reduce the marginal utility of consuming the domestically produced good. If consumers care more about damage caused by domestic pollution than, say, damage caused by pollution in a foreign country, then it is conceivable that they will prefer to buy the foreign-produced commodity provided price differences are not large. Consider a variation of this example. Suppose that production causes less global environmental damage in some countries than in others. This could be because of a nontransferable technology difference across countries or, more importantly, because of differences in the natural abatement capacity of the ecosystem in different countries. If price differences are not large, consumers who are concerned about global environmental change might prefer to buy the output produced in the country where production causes least environmental damage.

There are other interesting examples. Nationalism has often led people to prefer

\footnotetext{
*Roy: Erasmus University, 3000 DR Rotterdam, The Netherlands. Tel: (+31)-10-4081420; Fax: 2121724; E-mail: roy@few.eur.nl. Viaene: Erasmus University, 3000 DR Rotterdam, The Netherlands. Tel: $(+31)-10-$ 4081397; Fax: 4525808; E-mail: viaene@few.eur.nl. Helpful comments are gratefully acknowledged from H. P. Bowen, seminar participants at the Tinbergen Institute, University of Leuven, Konstanz University, the 1994 Maastricht EEA Conference, the 1995 Thessaloniki ERWIT Conference, and the 1995 Aix-enProvence Conference on "Recent Developments in International Economics." The current version of this paper has significantly benefited from the comments made by an anonymous referee.
} 
domestically produced output to a foreign-produced version of the same good. ${ }^{1}$ The widespread boycott of South African products by consumers across the world in the movement against "apartheid" is another example of how country of origin of a product has been used to differentiate it.

However, the most widespread reason for differentiation by country of origin is reputation. Historical experience, media and other factors often create myths which associate country of production with good quality and snob effect. While the connoisseur may differentiate between specific brand names, for large number of consumers in distant countries "Belgian chocolate," "French wine or perfume," "Spanish boots," and "Dutch cheese" are differentiated from similar products in other countries. Nowhere is it stronger than in the less industrialized countries, where domestically produced goods are severely discounted (even if they are of similar physical "quality") vis-à-vis products from Western countries. Often the differentiation is simply by the country of origin rather than specific brand names, ${ }^{2}$ though the latter is certainly important for the more literate consumers. This aspect of the so-called "international demonstration effect" (Duesenberry, 1949; Nurkse, 1953) is one of the reasons why governments in such countries do not wish to allow free import of consumer goods from abroad.

It is clear that economic forces determine, as much as they reflect, such country biases in consumer preferences. The question of how such country biases are formed and sustained is an important problem for social scientists. The issues addressed in this paper are, however, more modest. We concentrate on the implications of country bias for international trade theory, taking the existence of such bias in the preferences as exogenously given.

An important qualitative result that emerges from our analysis is the crucial role that preferences play in determination of the pattern of production specialization and trade across countries. In the standard neoclassical trade model, it is well known that preferences play a role in determining the comparative advantage of nations and their production pattern under free trade. ${ }^{3}$ Introduction of country bias in preferences increases the potential role of demand-side factors in determining the nature of sectoral resource allocation in free trade equilibrium. In order to bring out this increased role of preferences sharply, we adopt the classical Ricardian model with one primary factor, constant-returns technology and competitive markets for all commodities. A representative consumer is assumed for each country, and country bias in preferences is introduced by allowing the marginal rate of substitution between units of the same commodity, produced in different countries, to be different from unity. We characterize the pattern and composition of trade and production that emerges in the presence of such country bias.

The first contribution of this paper is to show that even in a classical Ricardian world, the presence of country bias makes preferences an important and, sometimes, the dominant factor in determining which physical commodity is produced, exported and imported in trade equilibrium. As we show, strong country bias may reverse the patterns of production specialization and trade suggested by technology and factor endowments. In particular, it is possible that each country produces and exports, under free trade, only that commodity in which it has a "comparative disadvantage" in the Ricardian sense. ${ }^{4}$

The observed pattern of trade in the modern world shows a large, sometimes a dominant, prevalence of intraindustry trade. Countries often export and import similar physical commodities. The neoclassical theories of trade which use a competitive framework predict that trade can only be of an interindustry nature; countries cannot export and import the same commodity. In recent decades, theoretical models of oli-

C Blackwell Publishers Ltd 1998 
gopoly and monopolistic competition with product differentiation have been used to explain the wide prevalence of intraindustry trade (Helpman, 1981; Venables, 1985, 1987). The presence of increasing returns can also be shown to lead to intraindustry trade (Ethier, 1979; Helpman and Krugman, 1985). Our paper demonstrates that in the presence of country bias in preferences, intraindustry trade can emerge even in a classical competitive world with constant-returns technology. In fact, both interindustry and intraindustry trade can occur simultaneously. Thus, the prevalence of intraindustry trade is not necessarily due to market imperfection, strategic behavior or product differentiation by producers. This is the second contribution of our paper.

In standard trade models, when countries move from autarky to free trade, there are welfare gains arising from specialization in production and exchange of output. Recent literature has emphasized the fact that free trade increases product variety which leads to welfare gains. Our analysis indicates a similar phenomenon. Suppose that consumer preferences are biased in favor of foreign products. By definition, in autarky, no supply of foreign products is available. The opening of free trade may allow domestic consumers to buy foreign products. This leads to gains from trade, even if no gains are forthcoming from reorganization of production structure among trading nations.

We begin by considering a world with one physical good. We show how and when trade can occur in the presence of country bias and how the terms of trade are biased in favor of countries with smaller production potential. After this, we analyze a world with two physical goods, one of which is differentiated in the sense that preferences exhibit country bias with respect to this commodity. We show that a complex set of possibilities about the pattern of production and trade emerges. Depending on factor endowments, preferences and technology, ten different types of configuration are possible. These include situations where both countries produce both commodities and interindustry as well as intraindustry trade occur, as also configurations in which specialization is exactly the reverse of that suggested by Ricardian comparative advantage.

\section{Trading in a World of One Physical Good}

Consider a simple world where there are two countries and only one homogenous physical good. Let us name the two countries Country 1 and Country 2 . Let $L_{i}$ and $a_{i}$ denote, respectively, the total endowment of the single primary factor and the output per unit of the factor in Country $i$. Let $Y_{i}=L_{i} a_{i}$ denote the total production capacity of Country $i$. In a trade equilibrium, we shall denote by $p_{i}$ the price of the good produced by Country $i$.

We assume a specific form for the utility function (of the representative consumer) in each country. The utility function of Country $i$ is given by

$$
U^{i}\left(C_{y i}^{i}, C_{y i}^{i}\right)=C_{y i}^{i}+\beta_{i} C_{y j}^{i}, \quad i, j=1,2, j \neq i,
$$

where $C_{y i}^{i}$ is the consumption of own output by Country $i$ and $C_{y j}^{i}$ is the amount imported. Note that $\left(1 / \beta_{i}\right)$ is the (constant) marginal rate of substitution between domestic and foreign output. This form of the utility function allows us to capture the extent of country bias by a single parameter, namely $\beta_{i}$. If $\beta_{i}=1$, there is no differentiation between foreign and domestic output by Country $i$. Consumers perceive the output of both countries to be perfect substitutes and there is no possibility of international trade; the total consumption in each country equals its total output. However, possibilities for trade open up with intercountry differentiation of the good by consumers. If $\beta_{i}>1$, then consumers in Country $i$ prefer to consume foreign output pro- 
vided the terms of trade are not too averse. On the other hand, if $\beta_{i}<1$, Country $i$ discounts the consumption of the foreign good in favor of the domestic good. It is easy to see that Country $i$ spends all its income on the domestic good if $\left(p_{i} / p_{j}\right)$ $<\left(1 / \beta_{i}\right)$ and imports all its consumption from abroad if $\left(p_{i} / p_{j}\right)>\left(1 / \beta_{i}\right)$. If $\left(p_{i} / p_{i}\right)=\left(1 / \beta_{i}\right)$, then every allocation of a country's income between domestic and foreign product is utility-maximizing.

International trade can occur if and only if both countries import. This is possible if the international price ratio satisfies

$$
1 / \beta_{i} \leq p_{i} / p_{i}, \quad i=1,2 \text {. }
$$

We can classify the trade equilibria that arise in this world into two types. The first is the case where each country exchanges its total domestic output for the total output of the foreign country. In the second type of equilibrium, the international price ratio is equal to the marginal rate of substitution for at least one country and this country consumes both foreign and domestic goods.

We begin by analyzing the first type of equilibrium where each country consumes only foreign output. Balance of trade requires

$$
p_{i} / p_{j}=Y_{j} / Y_{i}
$$

Expressions (1) and (2) indicate that such an equilibrium with trade is possible if

$$
1 / \beta_{i} \leq Y_{i} / Y_{i}, \quad i=1,2 \text {. }
$$

Note that if equilibrium is of this type, then the terms of trade are biased in favor of the country with smaller production potential. As can be observed from (3), the consumption per unit of factor input in Country $i$ is increasing in the production capacity of Country $j$ and decreasing in the size of its own factor endowment and in the average productivity of this factor. In some sense, the "smaller" country earns a "scarcity rent."

In autarky, the welfare of each country is given by $U^{i}=Y_{i}$, no matter what $\beta_{1}, \beta_{2}$ are. If free trade is allowed and an equilibrium with trade occurs, then the welfare of Country $i$ is given by $U^{i}=\beta_{i} Y_{j}$. From (3), we have $\beta_{i} Y_{j} \geq Y_{i}$ so that no country is worse off under free trade. While the country with greater production potential consumes less, it derives greater utility from this consumption because of country bias in favor of the foreign product and the fact that its entire consumption is imported. The greater $\beta_{i}$ is relative to $\left(Y_{i} / Y_{i}\right)$, the larger is the gain from trade for Country $i$.

Next, we analyze the second type of trade equilibrium. Suppose one country (say, $i$ ) consumes both foreign and domestic output while the other country $(\mathrm{say}, j)$ consumes only the imported good. This can occur only if the price ratio satisfies

$$
\left(p_{i} / p_{i}\right)=1 / \beta_{i} \text {. }
$$

Let $s_{i} \in(0,1)$ be the fraction of domestic output consumed by Country $i$. In equilibrium:

$$
\left(1-s_{i}\right) Y_{i}=Y_{j}\left(p_{j} / p_{i}\right)=Y_{i} \beta_{i}
$$

Existence of such an equilibrium therefore requires

$$
Y_{i} / Y_{i}<1 / \beta_{i}
$$

Combining (1), (4) and (5), we can check that a trade equilibrium where Country $i$ consumes both foreign and domestic product and country $j$ exchanges all its output for the foreign product exists if and only if 


$$
\beta_{i} \beta_{j} \geq 1 \text { and } Y_{j} / Y_{i}<1 / \beta_{i}
$$

In such an equilibrium, Country $i$ consumes $\left[Y_{i}-\beta_{i} Y_{j}\right]$ of domestic output and imports foreign output equal to $Y_{j}$. Country $j$ 's consumption is equal to its total import $\left[\beta_{i} L_{j} a_{j}\right]$. There are no gains from trade accruing to Country $i$ while Country $j$ has a gain from trade equal to $\left[\left(\beta_{1} \beta_{2}-1\right) Y_{j}\right]$. It can be verified that if $\left(1 / \beta_{1}\right)=\beta_{2}$, neither country gains from trade and, in fact, there exists a continuum of trade equilibria where both countries export as well as consume their output.

Combining (3) and (6), we can conclude that an equilibrium where trade occurs between the two countries exists if and only if

$$
\beta_{1} \beta_{2} \geq 1 \text {. }
$$

One implication of this is that, in our simple world, the possibility of trade depends only on the extent of country bias in preferences. Further, trade occurs even if one country does not differentiate or has pro-domestic preferences provided the other country has sufficiently pro-foreign preference. If $\beta_{i} \leq 1$ for $i=1,2$ (that is, both countries have pro-domestic preferences), then (7) cannot hold and there is no equilibrium with trade. Relative factor endowment and productivity play a role only in determining the terms of trade and the welfare gains resulting from trade. We summarize the above discussion in the following proposition.

Proposition 1. (a) There exists an equilibrium where trade occurs if, and only if, $\beta_{l} \beta_{2} \geq 1$. (b) Assume $\beta_{1} \beta_{2} \geq 1$. If $1 / \beta_{i} \leq\left(Y, Y_{i}\right), i, j=1,2$, then each country exports its entire domestic output and consumes only the foreign product, the country with lower production capacity has higher total consumption, the international price ratio $p_{i} / p$, is equal to $Y, Y_{i}$, and the welfare gain from trade (relative to autarky) for Country $i$ is equal to $\left[\beta_{i} Y_{j}-Y_{i}\right]$. On the other hand, if $1 / \beta_{i}>Y_{j} / Y_{i}$ for some $i$, then the trade equilibrium is such that the international price ratio $\left(p_{i} / p_{i}\right)=\left(I / \beta_{i}\right)$, Country $i$ consumes both domestic and foreign output and has no gain from trade while Country $j$ has a gain from trade equal to $\left[\beta_{1} \beta_{2}-1\right] Y_{j}$. Ceteris paribus, the gain from trade for Country $i$ is nonincreasing in its relative output potential $\left(Y_{t} / Y_{j}\right)$.

In this simple world, while intercountry differentiation by consumers can lead to emergence of trade it does not change the way production is organized across the world. In order to obtain that, we introduce at least one other physical commodity which is produced and, hence, competes for use of the production factor. The next section analyses such a Ricardian world.

\section{Country Bias and Trade in a World with Two Physical Commodities}

\section{The Structure}

In this section we move beyond the world of one physical commodity and consider a setting where, in addition to the differentiated good $y$ considered before, each country can use its endowment of the production factor to produce a nondifferentiated good $x$. We shall denote by $q_{i}$ the price of the output of good $x$ by Country $i$, while continuing to denote by $p_{i}$ the price of good $y_{i}$. All commodities are tradeable and produced competitively under constant returns to scale, with a technology that may differ between the countries. Let $b_{i}$ denote Country $i$ 's (constant) marginal productivity of 
the primary factor in production of good $x$. The total output of the two physical goods in Country $i(i=1,2)$ is given by

$$
\begin{aligned}
& Y_{i}=a_{i}\left(1-\gamma_{i}\right) L_{i}, \\
& X_{i}=b_{i} \gamma_{i} L_{i},
\end{aligned}
$$

where capitals are used to denote the quantity of output of each product in each country, and $\gamma_{i}$ the fraction of Country $i$ 's factor endowment that is used for the production of good $x\left(0 \leq \gamma_{i} \leq 1\right)$. Let $w_{i}$ denote the factor price in Country $i$.

As before, we assume that there is a representative consumer in each country. The utility function of the consumer in Country $i$ is assumed to be of the specific form

$$
U^{\prime}\left(C_{x}^{i}, C_{i y}^{i}, C_{j y}^{i}\right)=\left(C_{x}^{i}\right)^{\alpha}\left(C_{y i}^{i}+\beta_{i} C_{y j}^{i}\right)^{1-\alpha} \quad i=1,2, j \neq i, 0<\alpha<1,
$$

where $C_{x}^{i}, C_{y i}^{i}$, and $C_{y j}^{i}$ are Country $i$ 's consumption of, respectively, goods $x, y_{i}$, and $y_{j}$. Each country spends a fraction $\alpha$ of its income on good $x$ and $(1-\alpha)$ on the differentiated good $y$. The latter part of income is either spent on the domestic output of good $y$ (that is, $y_{i}$ ) or on foreign output of good $y$ (that is, $y_{j}$ ), depending on how the international price ratio $\left(p_{i} / p_{j}\right)$ compares to consumer $i$ 's marginal rate of substitution $\left(1 / \beta_{i}\right)$. The demand function for good $x$ in Country $i$ is, therefore, given by

$$
C_{x}^{i}=\alpha\left(w_{i} L_{i}\right) / q_{i}
$$

If $\left(p_{i} / p_{j}\right)<\left(1 / \beta_{i}\right)$, then the demand for $y_{i}$ and $y_{j}$ are given by

$$
C_{y i}^{i}=\left[(1-\alpha)\left(w_{i} L_{i}\right)\right] / p_{i}, \quad C_{y j}^{i}=0 .
$$

On the other hand, if $\left(p_{i} / p_{j}\right)>\left(1 / \beta_{i}\right)$, then

$$
C_{y i}^{i}=0, \quad C_{y j}^{i}=\left[(1-\alpha)\left(w_{i} L_{i}\right)\right] / p_{j} .
$$

If $\left(p_{i} / p_{j}\right)=\left(1 / \beta_{i}\right)$, then any bundle $\left(C_{y i}^{i}, C_{y j}^{i}\right) \geq 0$ such that $p_{i} C_{y i}^{i}+p_{j} C_{y j}^{i}=\left[(1-\alpha)\left(w_{i} L_{i}\right)\right]$ lies in the demand correspondence.

\section{Characterization of Equilibria}

Autarky First consider the equilibrium in each economy under autarky. In autarky, the international exchange of goods is not allowed; though consumers may have knowledge of foreign products, they are constrained to consume only domestic output (the price of good $y_{j}$ in Country $i$ can be set large enough so that there is no demand for $\left.y_{j}\right)$. The specific values of $\beta_{1}$ and $\beta_{2}$ have no role in determining the autarkic resource allocation in each country. Market clearing in equilibrium requires that $X_{i}=C_{x}^{i}$ and $Y_{i}=C_{y i}^{i}$. Let the primary factor be the numéraire commodity. Then, (8) through (11) can be used to show that the equilibrium prices (using labor as the numeraire commodity) and factor allocation in autarky in Country $i$ are given by

$$
w_{i}=1, \quad q_{i}=1 / b_{i}, \quad p_{i}=1 / a_{i}, \quad \gamma_{i}=\alpha .
$$

Free trade The opening of free international trade allows country bias in preferences to have a role in determining the allocation of resources and pattern of trade. Suppose that $b_{1} / b_{2}>a_{1} / a_{2}$. Then, Country 1 has a technological comparative advantage (in the Ricardian sense) in the production of good $x$ and Country 2 in the production of good $y$. If there are no country biases in preferences (that is, $\beta_{1}=\beta_{2}=1$ ) then we are in the 
classical Ricardian model. Given the specification of $U_{i}$, there is a unique free-trade equilibrium where at least one country specializes completely in production of the good in which it has a comparative advantage. Trade is of an interindustry nature with Country 1 exchanging good $x$ for import of good $y$ from Country 2. In particular, if

$$
\left(b_{1} / b_{2}\right) \geq[\alpha /(1-\alpha)]\left[L_{2} / L_{1}\right] \geq\left(a_{1} / a_{2}\right)
$$

then Country 1 specializes completely in the production of good $x$ and Country 2 specializes completely in good $y$.

These features change once we allow for country bias in preferences. Suppose that initially $\beta_{1}=\beta_{2}=1$ and that (14) holds. The trade equilibrium is one with complete specialization in production as in the classical Ricardian model. Now suppose that, for some reason, there is a preference shift in Country 1 so that $\beta_{1}<1$. Given the equilibrium prices, it is easy to see that for $\beta_{1}$ sufficiently small, $1 / \beta_{1}>p_{1} / p_{2}$ so that consumers in Country 1 demand only domestically produced good $y$ and do not wish to import Country 2's output of the same commodity. The Ricardian equilibrium, where Country 2 specializes entirely in the production of good $y$ and exports the same good to Country 1 , is no longer sustainable. Similarly, a sufficient increase in $\beta_{2}$ will imply that, given equilibrium prices, consumers in Country 2 demand only foreignproduced version of good $y$, and thus an equilibrium where Country 1 only produces $\operatorname{good} x$ is no longer sustainable. Different combinations of $\left(\beta_{1}, \beta_{2}\right)$ can lead to widely different new equilibrium configurations. The next proposition indicates the possible configurations that may arise. The production and trade flows under each configuration is denoted by a quadruple: [goods produced by country 1, goods produced by country 2 ; goods exported by country 1 , goods exported by country 2 ].

Proposition 2. Suppose that $b_{1} / b_{2}>a_{1} / a_{2}$, that is, Country 1 has a technological comparative advantage in commodity $x$ and Country 2 in commodity $y$. Country bias in preferences can lead to one of the following free-trade equilibrium outcomes: (i) No trade, (ii) Ricardian Outcome, (iii) Reversal of Ricardian Outcome, and (iv) Intraindustry trade. In particular, the pattern of specialization and trade occurring in equilibrium is one of the following configurations:

(A) [xy, xy; 0,0]: Equilibrium with no trade where each country produces both physical goods.

(B) $[x, y ; x, y]$ : Country 1 specializes completely in good $x$ while Country 2 in good $y$. Trade is interindustry as in the classical Ricardian pattern.

(C) $[x, x y ; x, y]$ or $[x y, y ; x, y]$ : One country specializes completely in production of one good while the other country diversifies. Trade is interindustry as in the classical Ricardian pattern.

(D) $[y, x ; y, x]$ : Country 1 specializes completely in good $y$ and Country 2 in good $x$. Each country specializes in the production and export of the commodity in which it has a technological "comparative disadvantage." Trade is interindustry and the reverse of the Ricardian prediction.

(E) $[x y, x ; y, x]$ or $[y, x y ; y, x]$ : One country completely specializes in the good in which it has a technological "comparative disadvantage" and the other diversifies. Trade is interindustry and the pattern is exactly the reverse of the Ricardian prediction.

(F) $[y, x y ; y, x y]$ : Country 1 specializes completely in good y but Country 2 produces both goods. Trade is interindustry as well as intraindustry; Country 2 exports both goods $x$ and $y$ in exchange for foreign output of good $y$.

(G) $[x y, y ; x y, y]$ : Country 1 produces both goods, Country 2 specializes completely 
in good y. Trade is interindustry and intraindustry: Country 1 exports both goods and imports good $y$.

(H) $[x y, x y ; x y, y]$ or $[x y, x y ; y, x y]$ : Each country produces both physical goods and trades. $A s$ in $(F)$ and $(G)$, trade is both interindustry and intraindustry.

Before proceeding further, we wish to clarify that in configurations $\mathrm{F}, \mathrm{G}$, and $\mathrm{H}$ where both countries produce good $y$ and intraindustry trade occurs, trade equilibria can be of two types: (i) each country consumes only the imported version of good $y$ and exports its entire domestic output; (ii) at least one country consumes a part of domestic output of good $y$ in addition to the imported version. The latter case can occur only when $p_{i} / p_{j}=1 / \beta_{i}$ and, in fact, the set of parameter values for which such equilibria can arise is negligible (lower dimensional set). For ease of exposition, we shall abstract from equilibria of type (ii) while analyzing these configurations. Also, it is possible that for particular parameter combinations equilibrium configurations are of type $[x y$, $x y ; x, y],[x y, x y ; y, x]$ or $[x y, x y ; y, y]$. It can be checked that they can occur only on a negligible set of parameters, and hence are not listed under Proposition 2.

It is possible to derive the precise conditions on the parameter space under which the different configurations $(\mathrm{A})-(\mathrm{H})$ arise in free-trade equilibrium. To illustrate how such conditions are derived, consider configuration $\mathrm{H}$ where both countries produce both commodities and intraindustry as well as interindustry trade occurs. Normalize prices in free trade equilibrium by setting $w_{1}=1$. Zero profit conditions for firms imply

$$
q_{1}=1 / b_{1}, \quad p_{1}=1 / a_{1}, \quad q_{2}=w_{2} / b_{2}, \quad p_{2}=w_{2} / a_{2} .
$$

Since good $x$ is not differentiated, it must be true that in equilibrium $q_{1}=q_{2}$. This allows us to solve for $w_{2}$ and, hence, $p_{2}$ :

$$
w_{2}=b_{2} / b_{1}, \quad p_{2}=\left(1 / a_{2}\right)\left(b_{2} / b_{1}\right) .
$$

Using (10), we obtain the world demand for good $x$. The total supply of good $x$ depends on $\gamma_{1}$ and $\gamma_{2}$. Market clearing requires

$$
\alpha\left[L_{1}+\left(b_{2} / b_{1}\right) L_{2}\right]=\left(\gamma_{1} b_{1} L_{1}+\gamma_{2} b_{2} L_{2}\right) q_{1} .
$$

As both countries produce both goods and trade occurs (which distinguishes it from the zero trade configuration $\mathrm{A}[x y, x y ; 0,0])$, consumers in both countries demand the foreign-produced version of good $y$. For, suppose not. Then one country consumes only the domestically produced $y$. The other country cannot export its output of good $y$ and so must be consuming it. This implies that the only possible trade is each country exporting good $x$ as well as importing it. As there is no intercountry differentiation with respect to good $x$, this is impossible. Thus, the demand for $y_{1}$, in equilibrium, emanates from Country 2 which spends $(1-\alpha)$ fraction of its income on this good (as indicated carlier, in this configuration we abstract from the borderline case where a country consumes a mix of foreign as well as domestic output of good $y$ ). Market clearing for good $y_{1}$ requires

$$
\left[(1-\alpha)\left(b_{2} / b_{1}\right) L_{2}\right] /\left[1 / a_{1}\right]=\left(1-\gamma_{1}\right) a_{1} L_{1} .
$$

From (17) and (18), we obtain

$$
\gamma_{i}=1-(1-\alpha)\left(b_{j} / b_{i}\right)\left(L_{j} / L_{i}\right), \quad i, j=1,2, i \neq j .
$$

As, $\gamma_{1}>0$ and $\gamma_{2}>0$ we must have

$$
(1-\alpha)<\left(b_{2} / b_{1}\right)\left(L_{2} / L_{1}\right)<1 /(1-\alpha) .
$$


As remarked earlier, for trade to take place it must be the case that each country consumes foreign-produced $y$ which requires that $p_{1} / p_{2} \in\left[1 / \beta_{1}, \beta_{2}\right]$; that is:

$$
\left(1 / \beta_{1}\right) \leq\left(b_{1} / b_{2}\right) /\left(a_{1} / a_{2}\right) \leq \beta_{2} \text {. }
$$

(H1) and $(\mathrm{H} 2)$ are the conditions under which configuration $\mathrm{H}$ occurs.

A similar reasoning enables us to derive conditions on the parameters that lead to the other equilibrium configurations. These conditions are listed in the Appendix. ${ }^{5}$ It should be remarked here that for particular regions in the parameter space, there may not exist any competitive equilibrium with free trade. Nonexistence of equilibrium arises owing to certain combinations of country bias parameters in the preferences, given the endowments and technologies of the two countries. In the rest of this section, we shall analyze the qualitative nature of parameters, in particular country bias, which results in the different equilibrium configurations and how they depart from classical Ricardian outcomes.

Equilibrium with no trade Equilibrium configuration $\mathrm{A}[x y, x y ; 0,0]$ is one where no trade occurs even though free trade is allowed. Such an autarkic equilibrium can never occur in the absence of country bias. However, when consumers in both countries have strong preference for domestic output relative to import $\left(\beta_{i}<1\right.$ and small), no country wishes to import good $y$ from abroad at prices consistent with the zero profit condition. As good $x$ is not differentiated, countries cannot both export and import good $x$ and so trade is not possible. Country 1 , whose technological comparative advantage is in good $x$, must have particularly strong pro-domestic country bias so that it is willing to consume relatively high-cost domestic output of good $y$. In general, xenophobic preferences lead to autarky.

Classical Ricardian outcomes Configurations $\mathrm{B}[x, y ; x, y], \mathrm{C}\{[x, x y ; x, y]$ or $[x y, y ; x$, $y]\}$ are classical Ricardian outcomes; each country specializes in the production and export of the physical commodity in which it has technological comparative advantage. Trade is interindustry. Configuration $B$ is one with complete specialization in production by both countries. In the absence of country bias, such complete specialization requires certain restrictions on the preferences and relative size of factor endowments as given by condition (14). The presence of country bias in preferences implies that a modified condition (Condition (B1) in the Appendix), incorporating the country bias parameters, needs to be satisfied in order to obtain this complete specialization outcome. Configuration $\mathrm{C}$ is the classical Ricardian outcome with incomplete specialization in production by one of the two countries.

If $\beta_{1}=\beta_{2}=1$ (that is, no country bias exists in preferences), the trade equilibrium is always one of the two configuration $B$ or C. However, in the presence of country bias, classical Ricardian outcomes emerge only when there is sufficient pro-domestic country bias in Country 2 (which has a comparative advantage in the production of the differentiated good $y$ ) and commensurate pro-foreign country bias in Country 1; they ensure that Country 1 exports good $y$ in trade equilibrium, but Country 2 does not.

Reversal of Ricardian specialization Configurations $\mathrm{D}[y, x ; y, x], \mathrm{E}\{[x y, x ; y, x]$ or $[y$, $x y ; y, x]\}$ are the ones where the classical Ricardian pattern of specialization and trade, predicted on the basis of technology difference between countries, is completely reversed owing to country bias. Both countries go for complete specialization in configuration $\mathrm{D}$, with each country producing only the commodity where it has a technological "comparative disadvantage." This is exactly the reverse of the classical 
configuration $\mathrm{B}[x, y ; x, y]$. In configuration $\mathrm{E}$, one country specializes completely in the commodity in which it has a comparative disadvantage (mirror images of configuration $\mathrm{C}\{[x, x y ; x, y]$ or $[x y, y ; x, y]\}$ while the other country specializes incompletely. In both configurations, trade is interindustry; each country exports only that commodity in which it has a "comparative disadvantage."

Let us examine the conditions under which the reversal-configuration $\mathrm{D}[y, x ; y, x]$ can occur. As Country 1 consumes its own output of $y$ while Country 2 consumes only foreign output of the same good, it must be true that $p_{1} / p_{2} \leq 1 / \beta_{1}$ and $p_{2} / p_{1} \geq 1 / \beta_{2}$. As Country 2 exports good $x$ which is not differentiated, it must be true that $q_{1}=q_{2}=w_{2} / b_{2}$ $\leq 1 / b_{1}$. Similarly, as Country 1 produces good $y, p_{1}=1 / a_{1}$ and $p_{2} \leq w_{2} / a_{2}$. One can solve for $w_{2}$ from the market-clearing equation for good $x$ and obtain $w_{2}=[(1-\alpha) / \alpha]\left[L_{1} / L_{2}\right]$. One can find a price $p_{2}$ and an equilibrium allocation such that all the constraints indicated above are met, if and only if

$$
\left(a_{2} / a_{1}\right)\left[\max \left(\beta_{1}, 1 / \beta_{2}\right)\right] \leq[(1-\alpha) / \alpha]\left[L_{1} / L_{2}\right] \leq\left(b_{2} / b_{1}\right)
$$

However, by assumption $\left(b_{2} / b_{1}\right)<\left(a_{2} / a_{1}\right)$. So, a necessary condition for (D1) to hold is that $\beta_{1}<1$ and $\beta_{2}>1$. Further, suppose that $[(1-\alpha) / \alpha]\left[L_{1} / L_{2}\right] \leq\left(b_{2} / b_{1}\right)$. Then, for $\beta_{1}$ sufficiently small and $\beta_{2}$ sufficiently large, configuration $D$ necessarily occurs.

An examination of the conditions for configuration $E$ also indicates that it is associated with relatively low values of $\beta_{1}$ and high values of $\beta_{2}$. A small value of $\beta_{1}$ means that Country 1 (which imports commodity $y$ in a classical Ricardian world with no country bias) has strong bias in favor of domestic output of good $y$. A high value of $\beta_{2}$ on the other hand implies that Country 2 (which exports commodity $y$ in a classical world with no country bias) is highly biased in favor of the foreign output of good $y$. A combination of both leads to reversal of Ricardian patterns of trade and specialization.

Intraindustry trade Intraindustry trade occurs in equilibrium configurations $\mathrm{F}[y, x y$; $y, x y], \mathrm{G}[x y, y ; x y, y]$ and $\mathrm{H}\{[x y, x y ; y, x y]$ or $[x y, x y ; x y, y]\}$. In our model, intraindustry trade involves simultaneous export and import of the differentiated good $y$. This can occur in equilibrium only if the international prices are such that each country demands foreign output of the differentiated good and both countries produce the differentiated good. The former requires that $1 / \beta_{1} \leq p_{1} p_{2} \leq \beta_{2}$. This indicates that in any configuration where intraindustry trade occurs, the preference parameters must satisfy $\beta_{1} \beta_{2} \geq 1$. $^{6}$

For intraindustry trade to occur, no country must be completely specialized in the undifferentiated good $x$ and both countries must produce the differentiated good. Thus, in our model, intraindustry trade can occur simultaneously with interindustry trade. Also, observe that intraindustry trade configuration $\mathrm{G}[x y, y ; x y, y]$ is associated with reversal of the Ricardian prediction as Country 1 specializes in and exports only good $y$ in which it has a comparative disadvantage.

An examination of the precise conditions on parameters for configurations $F, G$ and $H$ shows that, as can be expected, they are associated with strong country bias in favor of the foreign output of commodity $y$ in both countries. In addition to $\beta_{1} \beta_{2} \geq 1, \beta_{2} \geq 1$ is a necessary condition; the country which has a technological comparative advantage in good $y$ must, in particular, exhibit pro-foreign bias.

Empirically, the extent of intraindustry trade is usually measured by Grubel and Lloyd's measure (1975):

$$
G L_{i}=1-\left|X_{i}-M_{i}\right| /\left(X_{i}+M_{i}\right), \quad i=1,2 \text {, }
$$


where $X_{i}$ and $M_{i}$ are the values of Country $i$ 's export and import of commodity $y$ on a bilateral basis. Seen from the perspective of Country 1, and using the demand specification (11) and (12), the Grubel-Lloyd measure can be rewritten as

$$
G L_{1}=1-(1-\alpha)\left(\left|w_{2} L_{2}-w_{1} L_{1}\right|\right) /(1-\alpha)\left(w_{2} L_{2}+w_{1} L_{1}\right)
$$

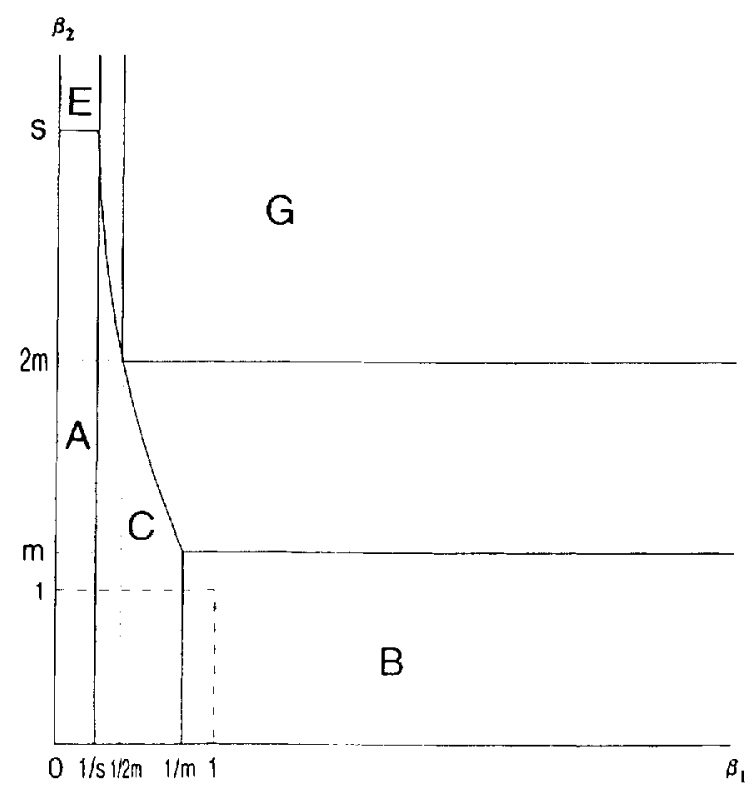

Figure 1, Equilibrium Configurations when $\left[b_{1} / b_{2}\right]>2$

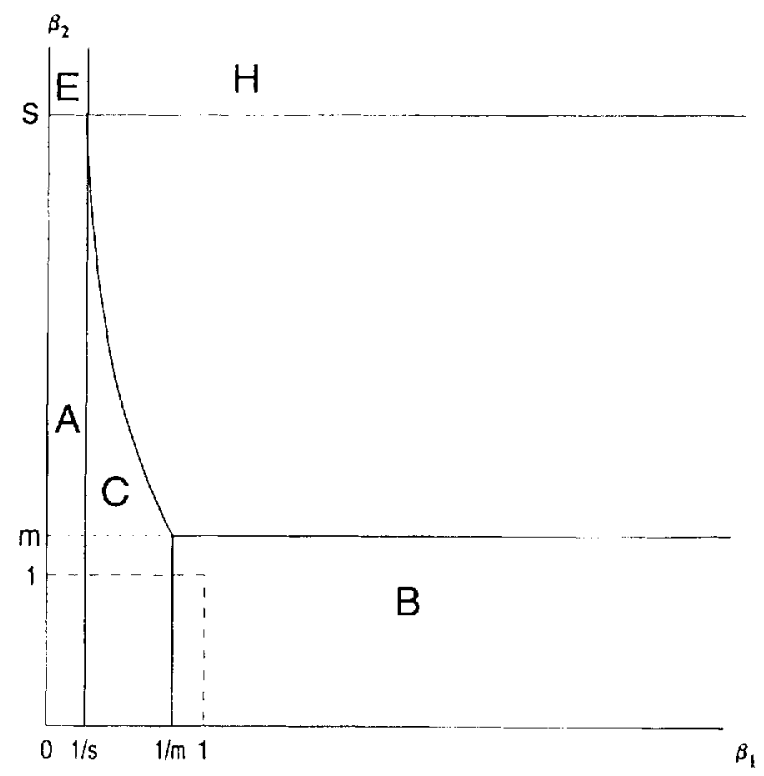

Figure 2. Equilibrium configurations when $1<\left[b_{1} / b_{2}\right] \leq 2$ 
Consider intraindustry trade configuration $\mathrm{H}\{[x y, x y ; y, x y]$ or $[x y, x y ; x y, y]\}$. Using (14), we obtain

$$
G L_{1}=1-|1-\lambda| /(1+\lambda),
$$

where $\lambda=b_{1} L_{1} / b_{2} L_{2}$. Values of $G L_{1}$ range between 0 and 1 . Intraindustry trade is maximum at $\lambda=1$; that is, when the maximum production capacity of good $y$ is iden-

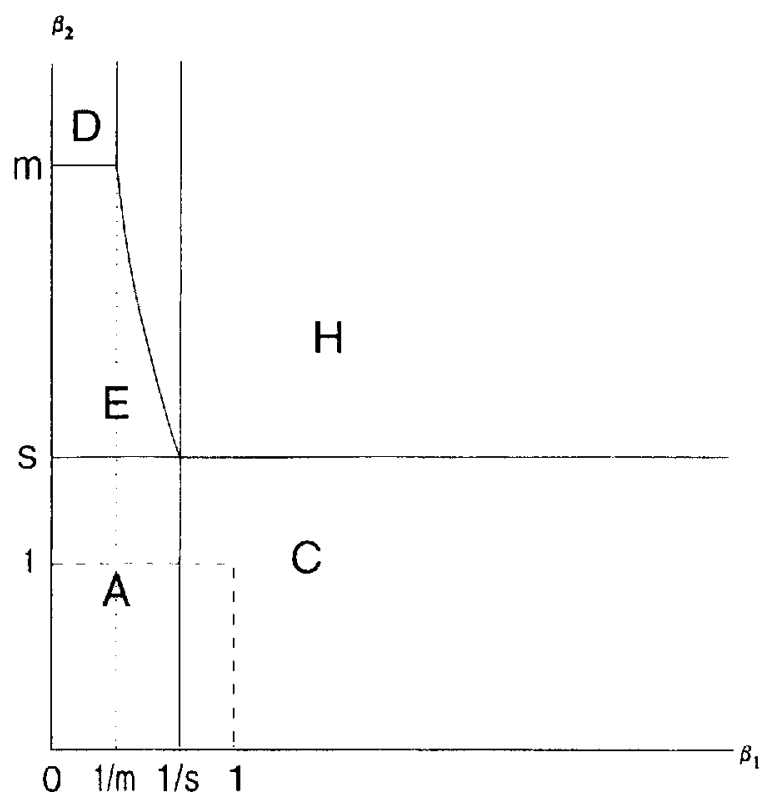

Figure 3. Equilibrium configurations when $\left.1 / 2<\mid b_{1} / b_{2}\right\rfloor \leq 1$

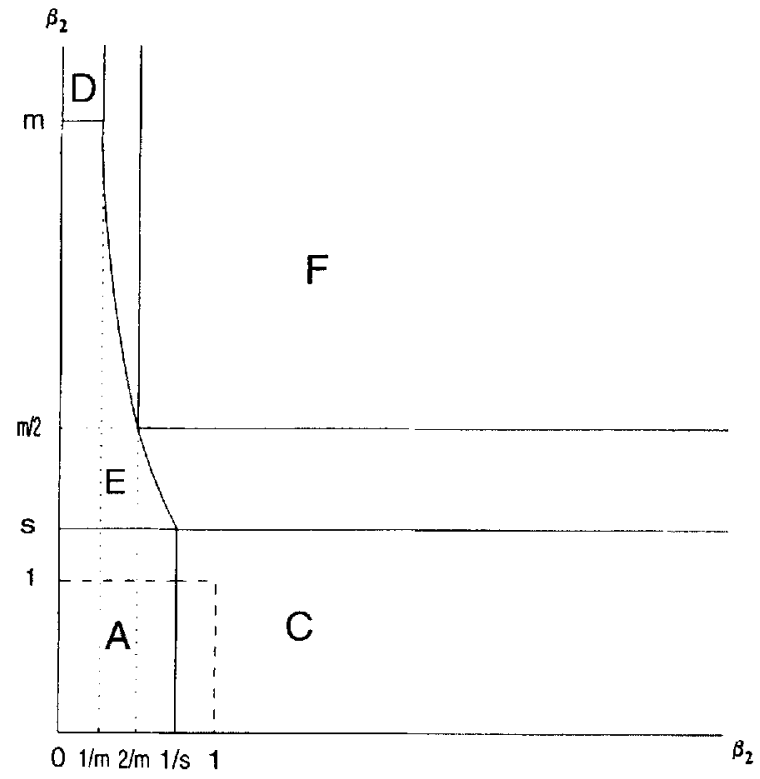

Figure 4. Equilibrium configurations when $\left[b_{1} / b_{2}\right] \leq 1 / 2$ 
tical in the two countries. With $\lambda>1$, Country 1 is a net importer (and with $\lambda<1$, a net exporter) of the differentiated commodity, the undifferentiated good being exported or imported to accommodate for trade-balance equilibrium.

Dependence on country bias The preceding discussion in this section has indicated that, depending on parameter values, the possible equilibrium configurations can be classified under:

1. autarkic: $\mathrm{A}[x y, x y ; 0,0]$

2. classical Ricardian Outcome: $\mathrm{B}[x, y ; x, y]$ and $\mathrm{C}\{[x, x y ; x, y]$ or $[x y, y ; x, y]\}$

3. reversals of classical Ricardian Outcome: $\mathrm{D}[y, x ; y, x]$ and $\mathrm{E}\{[x y, x ; y, x]$ or $[y, x y ; y, x]\}$

4. intraindustry trade: $\mathrm{F}[y, x y ; y, x y], \mathrm{G}[x y, y ; x y, y]$ and $\mathrm{H}\{[x y, x y ; y, x y]$ or $[x y, x y ; x y, y]\}$

We wish to examine precisely how, ceteris paribus, different combinations of country bias parameters $\beta_{1}$ and $\beta_{2}$ determine which of these four types of configurations occur. For clarity of exposition, we shall assume that $L_{1}=L_{2}$ and $\alpha=1 / 2$. As in Proposition 2 , we assume that $b_{1} / b_{2}>a_{1} / a_{2}$. The conditions determining the different configurations then depend on four parameters: $\left(a_{1} / a_{2}\right),\left(b_{1} / b_{2}\right), \beta_{1}$, and $\beta_{2}$. For ease of notation, denote the ratio $\left[\left(b_{1} / b_{2}\right) /\left(a_{1} / a_{2}\right)\right]$ by $s$ and the ratio $\left[a_{2} / a_{1}\right]$ by $m$. Note that $s>1$.

Figure 1 depicts the case where $\left[b_{1} / b_{2}\right]>2$. Here, the only possible configurations are A, B, C, E, and G. For very low values of $\beta_{1}\left(\beta_{1} \leq 1 / s<1\right)$ and $\beta_{2}$ not exceeding critical level $s$, the autarkic configuration $\mathrm{A}[x y, x y ; 0,0]$ occurs. For similarly low values of $\beta_{1}$, if $\beta_{2}$ exceeds critical level $s$, we have configuration $\mathrm{E}$ where there is interindustry trade with an exact reversal of Ricardian specialization. On the other hand, if $\beta_{2}$ is not very large but $\beta_{1}$ is moderately large, one of the classical Ricardian configurations $\mathrm{B}$ or $\mathrm{C}$ occurs. If the $\beta_{i}$ are sufficiently large in both countries, especially in Country 2 $\left(\beta_{1} \geq m / 2\right.$, and $\left.\beta_{2}>2 m\right)$, intraindustry trade configuration $\mathrm{G}[x y, y ; x y, y]$ occurs. Figures 2,3 and 4 depict the regions of the $\left(\beta_{1}, \beta_{2}\right)$ space corresponding to the various equilibrium configurations for the cases $1<\left[b_{1} / b_{2}\right] \leq 2,1 / 2<\left[b_{1} / b_{2}\right] \leq 1$ and $\left[b_{1} / b_{2}\right] \leq 1 / 2$, respectively. ${ }^{8}$ Observe that the general pattern is identical in all four figures. For configurations $\mathrm{C}$ and $\mathrm{E}$, the caption for each figure indicates the specific pattern of specialization associated with that case.

On the lower left corner is a region, where the autarkic equilibrium (A) occurs. This reflects extreme pro-domestic country bias in Country 1 which has a technological advantage in production of the differentiated good $y$ and not very high pro-foreign country bias in the other country. Therefore, Country 1 wants to consume its own output of good $y$, but it cannot export its relatively high-cost good $y$ to the other country as the latter's pro-foreign bias is not strong enough. So no trade is possible.

On the lower right side is a region where the pro-foreign bias of Country 2 is not large ( $\beta_{2}$ below a critical level) so that it would not like to import relatively "high-cost" foreign output of good $y$, and Country 1's bias is not excessively pro-domestic ( $\beta_{1}$ not very small) so that it is willing to import low-cost foreign output of good $y$. The net result is one of the classical Ricardian Outcomes B or C: Country 1 exports only good $x$ and Country 2 exports only good $y$.

On the upper left corner is a region where Country 1 has highly pro-domestic preferences (low $\beta_{1}$ ) matched by highly pro-foreign bias in Country 2 (high $\beta_{2}$ ). Thus, even though Country 1 has technological comparative advantage in the production of good $x$, it is willing to consume high-cost domestic output of good $x$ and is also able to export 
it to Country 2 whose preferences are highly foreign-biased. Thus, Country 1 specializes and exports good $y$ in exchange for good $x$ : a complete reversal of Ricardian specialization and trade pattern occurs; i.e. configuration D or E occurs.

In the upper right region, both countries have relatively high pro-foreign preference so that both countries are willing to buy foreign output of good $y$. Equilibrium, therefore, involves intraindustry trade; i.e. configuration $\mathrm{F}, \mathrm{G}$ or $\mathrm{H}$ occur.

Efficiency and trade Lastly, suppose that we ignore the differentiation of good $y$ by country of origin and simply concentrate on the way production of the physical goods $x$ and $y$ is organized across the world in free trade equilibrium. The departure from the Ricardian pattern of specialization in production means that the equilibrium output vector is below the world production possibility frontier in the space of two physical goods. Thus, for example, in configuration $\mathrm{H}[[x y, x y ; y, x y]$ or $[x y, x y ; x y, y]\}$ both countries specialize incompletely, which can never be an efficient way of producing the world consumption of the two physical commodities, given that we have one production factor and fixed input-requirement technology. However, in the space of three economic goods $\left(x, y_{1}, y_{2}\right)$ and given the restriction that Country $i$ cannot produce good $y_{j}$, free-trade equilibrium is always efficient.

\section{Conclusion}

The existence of country bias in preferences has important implications for the pattern of trade and specialization. Consumer preferences become a vital factor in determining the way in which production is organized across the world under free trade. Even in a classical Ricardian world, the pattern of specialization suggested by technological comparative advantage can be completely reversed in the presence of such country bias. Pro-foreign country bias can lead to equilibria with intraindustry trade. Country bias can increase or decrease the volume of trade.

\section{Appendix: Conditions Supporting Configurations (A)-(H) in Free-Trade Equilibrium}

Configuration A (no trade):

$$
\beta_{2} \leq\left[\left(b_{1} / b_{2}\right) /\left(a_{1} / a_{2}\right)\right] \leq\left(1 / \beta_{1}\right)
$$

Configuration $\mathrm{B}[x, y ; x, y]$ :

$$
\left(b_{2} / b_{1}\right) \leq[(1-\alpha) / \alpha]\left[L_{1} / L_{2}\right] \leq\left[\min \left(\beta_{1}, 1 / \beta_{2}\right)\right]\left(a_{2} / a_{1}\right)
$$

Configuration $\mathrm{C}\{[x, x y ; x, y]$ or $[x y, y ; x, y]\}$ :

$\lfloor x, x y ; x, y]$ occurs if:

$$
\begin{aligned}
& \left(b_{1} / b_{2}\right)\left(L_{1} / L_{2}\right)<[\alpha /(1-\alpha)] \\
& \max \left(1 / \beta_{1}, \beta_{2}\right) \leq\left[\left(b_{1} / b_{2}\right) /\left(a_{1} / a_{2}\right)\right]
\end{aligned}
$$

$[x y, y ; x, y]$ occurs if:

$$
\left[\left(a_{1} / a_{2}\right) /\left(b_{1} / b_{2}\right)\right] \leq \beta_{1}<[(1-\alpha) / \alpha]\left[L_{1} / L_{2}\right]\left[a_{1} / a_{2}\right]
$$

(C2') $\quad \beta_{1} \beta_{2} \leq 1$ 
Configuration D $[y, x ; y, x]$ :

(D1)

$$
\left(a_{2} / a_{1}\right)\left[\max \left(\beta_{1}, 1 / \beta_{2}\right)\right] \leq[\alpha /(1-\alpha)]\left[L_{1} / L_{2}\right] \leq\left(b_{2} / b_{1}\right)
$$

Configuration $\mathrm{E}\{[x y, x ; y, x]$ or $[y, x y ; y, x]\}$ :

$[x y, x ; y, x]$ occurs if:

$$
\begin{aligned}
& {[(1-\alpha) / \alpha]<\left(b_{1} / b_{2}\right)\left(L_{1} / L_{2}\right)} \\
& {\left[\left(b_{1} / b_{2}\right) /\left(a_{1} / a_{2}\right)\right] \leq \min \left(1 / \beta_{1}, \beta_{2}\right)}
\end{aligned}
$$

$[y, x y ; y, x]$ occurs if:

$$
\begin{aligned}
& {\left[\left(a_{2} / a_{1}\right) /\left(b_{2} / b_{1}\right)\right] \leq \beta_{2}<[(1-\alpha) / \alpha]\left[L_{2} / L_{1}\right]\left[a_{2} / a_{1}\right]} \\
& \beta_{1} \beta_{2} \leq 1
\end{aligned}
$$

Configuration $\mathrm{F}[y, x y ; y, x y]$ :

$$
\begin{aligned}
& \left(b_{1} / b_{2}\right)\left(L_{1} / L_{2}\right) \leq(1-\alpha) \\
& \left(1 / \beta_{1}\right) \leq(1-\alpha)\left(a_{2} / a_{1}\right)\left(L_{2} / L_{1}\right) \leq \beta_{2}
\end{aligned}
$$

Configuration $\mathrm{G}[x y, y ; x y, y]$ :

$$
\begin{aligned}
& 1 /\{1-\alpha] \leq\left(b_{1} / b_{2}\right)\left(L_{1} / L_{2}\right) \\
& \left(1 / \beta_{1}\right) \leq\{1 /(1-\alpha)\}\left\{\left(a_{2} / a_{1}\right)\left(L_{2} / L_{1}\right)\right\} \leq \beta_{2}
\end{aligned}
$$

Configuration $\mathrm{H}\{[x y, x y ; y, x y]$ or $[x y, x y ; x y, y]\}$ :

$$
\begin{aligned}
& (1-\alpha)<\left[\left(b_{2} / b_{1}\right)\left(L_{2} / L_{1}\right)\right]<[1 /(1-\alpha)] \\
& \left(1 / \beta_{1}\right) \leq\left(b_{1} / b_{2}\right) /\left(a_{1} / a_{2}\right) \leq \beta_{2}
\end{aligned}
$$

\section{References}

Bagwell, Kyle and Robert W. Staiger, "The Role of Export Subsidies when Product Quality is Unknown," Journal of International Economics 27 (1989):69-89.

Donnenfeld, Shabtai, "Inter-Industry Trade and Imperfect Information about Product Quality," European Economic Review 30 (1986):401-17.

Donnenfeld, Shabtai and Wolfgang Mayer, "The Quality of Export Products and Optimal Trade Policy," International Economic Review 28 (1987):159-73.

Duesenberry, James S., Income, Savings and the Theory of Consumer Behavior, Cambridge, MA: 1949.

Ethier, Wilfred J., "Internationally Decreasing Costs and World Trade," Journal of International Economics 9 (1979):1-24.

Grubel, Herbert G. and Peter J. Lloyd, Intraindustry Trade, London: Macmillan, 1975.

Helpman, Elhanan, "International Trade in Presence of Product Differentiation, Economies of Scale and Monopolistic Competition," Journal of International Economics 11 (1981):305-40.

Helpman, Elhanan and Paul R. Krugman, Increasing Returns under Imperfect Competition and International Trade, Cambridge, MA: MIT Press, 1985.

Neven, Damien, George Norman, and Jacques-Francois Thisse, "Attitudes towards Foreign Products and International Price Competition," Canadian Journal of Economics 24 (1991):1-11.

Nurkse, Ragnar, Problems of Capital Formation in Underdeveloped Countries, Oxford: Basil Blackwell, 1953.

Venables, Anthony, "Trade and Trade Policy with Imperfect Competition: The Case of Identical Products and Free Entry," Journal of International Economics 19 (1985):1-20. 
"Trade and Trade Policy with Differentiated Products: Chamberlinian-Ricardian Model," Economic Joumal 97 (1987):700-17.

\section{Notes}

1. The Swadeshi movement in India is a classic example of how consumers voluntarily "boycotted" foreign goods in order to support domestic producers.

2. Incomplete information about quality of specific foreign firms often leads to evaluation of foreign products according to perception of "average quality." This leads to the possibility of policy intervention as well as intraindustry trade (Bagwell and Staiger, 1989; Donnenfeld, 1986; Donnenfeld and Mayer, 1987).

3. In particular, preferences influence the autarkic price ratio; the commodities in which a country specializes and exports are those with lower relative autarkic prices compared with the other country.

4. Our model is in the standard general equilibrium framework. Commodities carry a geographical label. Each country can produce only some of the geographically labelled goods. The general equilibrium nature of the model distinguishes our analysis from Neven, et al. (1991) who focus on the implication of dispersion of country bias in the consumer population on the outcomes of oligopolistic price competition.

5. A detailed derivation is available on request from the authors.

6. Recall that this is also the nccessary and sufficient condition for trade in the one physical good world considered in section 2.

7. Except for the borderline case in configuration $\mathbf{H}$ where no country exports commodity $x$ (which occurs only if $b_{1} L_{1}=b_{2} L_{2}$ ), intraindustry trade is always accompanied by interindustry trade.

8. In Figures 1 and 2 , the point $\left(\beta_{1}=1, \beta_{2}=1\right)$ where there is no country bias is depicted as being under configuration $\mathrm{B}$, the Ricardian outcome with complete specialization. This is not necessary; it could also be under configuration $C$, the Ricardian outcome with incomplete specialization in one country. 